\title{
Responses of Andropogon pumilus Roxb. to Various Heights and Intervals of Clipping
}

\section{P. SINGH AND L. P. MALL}

Highlight: Andropogon pumilus Roxb. produced most dry matter (above ground and underground) when it was clipped at an interval of 45 days and at height of $15 \mathrm{~cm}$. The average seed output at this clipping was maximum.

A knowledge and appreciation of the morphology and growth habits of the species used and their responses to defoliation is very helpful in maintaining the desired proportion of grass and legumes in a forage stand. In an actively growing plant, all of the energy captured from sunlight is not utilized in the production of new plant tissue, but part of it is used in respiration and part of it is stored mainly in basal portions of the plant so that new leaves can be produced after defoliation. Thus a knowledge of the effect of defoliation at different stages of growth and at different frequency is essential in foreseeing the possible effect of grazing or cutting practices.

Many studies have sought to evaluate the influence of grazing by clipping herbage artificially. Although clipping does not simulate grazing precisely, a good appraisal of grazing can be attained by clipping treatment. A number of experiments for the study of the effect of frequency of clipping, and height of clipping on the yield of grass have shown that higher annual

\footnotetext{
Authors are lecturer and professor, School of Studies in Borany, Vikram University, Ujjain, 45610, India.

Manuscript received April 9, 1975.
}

yield can be expected from infrequent clipping (Albertson et al., 1953; Aldous, 1930; Baker et al., 1945; Canfield, 1939; McCarty, 1932; and Stoddart, 1946), and that cutting the grasses at different heights and stages of growth is effective (Owensby and Anderson, 1969; Smith et al., 1971; and Robinson et al., 1952).

Andropogon pumilus Roxb., a tufted annual grass with numerous radiating branches growing all directions, reaches 1 meter in height, and is found throughout India. Because of its extensive distribution, abundance, and palatability to livestock (Bor, 1941), the species was selected for study. The investigations were designed to determine its responses to various clipping intervals and height of herbage removal under favorable climatic environment (August to October). The responses were evaluated on the basis of herbage, roots, and seed production.

\section{Methods}

This experiment was conducted at the Departmental Botanical Garden in a Malwa clay loam (Singh, 1969), with level topography. Precipitation averages about $1,030 \mathrm{~mm}$, most of which occurs during the rainy season. Seedlings of $A$. pumilus Roxb. were grown in individual containers and transplanted on July 2 to the experimental plot. In all, 39 subplots (size $1 \mathrm{~m}^{2}$ ) were made. In each subplot the density and spacing of plants were kept uniform. Three subplots were left unclipped and 3 clipped at each combination of clipping heights (base, and 5,10 , and $15 \mathrm{~cm}$ ) and 3 intervals $(15,30$, 
Table 1. Herbage production $\left(\mathrm{g} / \mathrm{m}^{2}\right.$, oven dry) by frequency and height of clipping.

\begin{tabular}{|c|c|c|c|c|c|c|c|c|c|c|}
\hline \multirow{2}{*}{$\begin{array}{l}\text { Clipping } \\
\text { height }^{1} \\
(\mathrm{~cm})\end{array}$} & \multirow{2}{*}{$\begin{array}{l}\text { Clipping } \\
\text { frequency }\end{array}$} & \multirow{2}{*}{$\begin{array}{c}\text { Clipping } \\
\text { interval }^{2} \\
\text { (days) }^{\text {days }}\end{array}$} & \multicolumn{7}{|c|}{ Date clipping } & \multirow[b]{2}{*}{$\begin{array}{c}\text { Total } \\
\text { herbage }\end{array}$} \\
\hline & & & $\begin{array}{c}\text { Aug. } \\
20\end{array}$ & $\begin{array}{c}\text { Aug. } \\
5\end{array}$ & $\begin{array}{c}\text { Aug. } \\
20\end{array}$ & $\begin{array}{c}\text { Sept. } \\
5\end{array}$ & $\begin{array}{c}\text { Sept. } \\
20\end{array}$ & $\begin{array}{c}\text { Oct. } \\
5\end{array}$ & $\begin{array}{l}\text { Last } \\
\text { date }\end{array}$ & \\
\hline Unclipped & & & & & & & & & & 399.5 \\
\hline Base & 6 & 15 & 60.4 & 42.5 & 36.4 & 26.4 & 16.3 & 10.4 & 23.9 & 216.9 \\
\hline 5 & 6 & 15 & 53.4 & 36.4 & 40.5 & 45.3 & 49.4 & 51.3 & 39.5 & 315.7 \\
\hline 10 & 6 & 15 & 50.6 & 51.3 & 56.3 & 59.4 & 63.4 & 65.4 & 49.5 & 395.9 \\
\hline 15 & 6 & 15 & 43.9 & 52.4 & 57.3 & 62.4 & 69.3 & 70.4 & 55.2 & 410.9 \\
\hline Base & 3 & 30 & 63.7 & - & 73.5 & - & 93.5 & - & 63.5 & 294.2 \\
\hline 5 & 3 & 30 & 59.4 & - & 103.5 & - & 111.4 & - & 73.7 & 348.0 \\
\hline 10 & 3 & 30 & 51.2 & - & 109.3 & - & 121.3 & - & 95.9 & 377.7 \\
\hline 15 & 3 & 30 & 46.4 & - & 116.4 & - & 129.4 & - & 148.5 & 440.7 \\
\hline Base & 2 & 45 & 64.3 & - & - & 169.4 & - & - & 149.3 & 383.0 \\
\hline 5 & 2 & 45 & 57.4 & - & - & 189.5 & - & - & 193.4 & 440.3 \\
\hline 10 & 2 & 45 & 54.3 & - & - & 193.5 & - & - & 208.4 & 456.2 \\
\hline 15 & 2 & 45 & 49.3 & - & - & 206.3 & - & - & 218.5 & 474.1 \\
\hline
\end{tabular}

${ }^{1}$ L.S.D. $=71.8$.

${ }^{2}$ L.S.D. $=64.1$

Significant at $1 \%$ level.

and 45 days). The clipping frequencies were 6,3 , and 2 for the clipping intervals of 15,30 , and 45 days, respectively. Herbage production for each treatment was calculated on oven dry weight basis.

\section{Results and Conclusions}

\section{Herbage Production in Relation to Clipping}

It is clear from the Table 1 that greater herbage was produced when the plants were clipped at a height of $15 \mathrm{~cm}$ and at an interval of 45 days, as compared to $10 \mathrm{~cm}, 5 \mathrm{~cm}$, base heights, and 15-day and 30-day intervals of clipping. Yield is supposed to be a reflection of the clipping height. Daubenmire (1947) argues that basal meristems are likely to be injured in close clipping or grazing. Thus, $15 \mathrm{~cm}$ seems to be an optimum height for increased herbage production in $A$. pumilus.

Frequency of herbage removal had pronounced effect upon production of forage. Average production decreased with increased number of clipping. Clipping at 15- and 30-day intervals produced less herbage than clipping at a 45-day interval (Table 1). It may be concluded that biweekly and monthly clipping of the herbage reduced the amount of food materials available for translocation to the roots, so that the capacity to produce new tillers was reduced in $A$. pumilus. Similar results were found by Albertson et al. (1953), Aldous (1930), Baker et al. (1945), Brown (1943), Buckner and Henry (1945), Canfield (1939), and Stoddart (1946).

\section{Root Production in Relation to Clipping}

Data on quantity of root production under different treatments are given in Table 2. Plants clipped fewest times (30- and 45-day intervals) produced the greatest herbage yield. Frequent clipping (15 days) apparently leaves little time for herbage replacement; hence food manufacture and downward translocation is limited, causing retardation in root growth. This agrees with finding of Weinmann (1943), Lovvorn (1945), and Cook et al. (1958), who showed that increased frequency of clipping grasses significantly reduced the root yield. In general, treatments that produced the greatest herbage production likewise produced the greatest root yield. Plants in high vigor displayed a well-developed root system. It appears that any herbage removal reduces total root production. Albertson et al. (1953) and Biswell and Weaver (1933) have shown that an increase in frequency of clipping resulted in reduction in yield, depth, and spread of roots. Harrison (1931) clipped grasses at different heights and found that the amount of roots increased with the height to which the grasses were clipped. Stapledon and Beddows (1926) showed that the repeated cutting of Dactylis glomerata during the growing season not only decreased the amount of hay and aftermath crop but also reduced the root systems of the plants and retarded their growth early in the following spring.

Height of clipping had a significant effect upon root growth. The average yields for the base and $5 \mathrm{~cm}$ height were lower than those for grass clipped at $10 \mathrm{~cm}$ and $15 \mathrm{~cm}$ height (Table 2). The closer clipping reduces the herbage yield and this, in turn, root production.

Table 2. Root production $\left(\mathrm{g} / \mathrm{m}^{2}\right)$ under various heights of clipping and 3 clipping intervals.

\begin{tabular}{cccccc}
\hline \hline \multirow{2}{*}{$\begin{array}{c}\text { Clipping } \\
\text { intervals } \\
\text { (days) }\end{array}$} & \multicolumn{5}{c}{ Clipping height $(\mathrm{cm})^{1}$} \\
\cline { 2 - 6 } & Base & 5 & 10 & 15 & Mean \\
\hline 15 & 27.3 & 40.3 & 46.3 & 49.9 & 40.0 \\
30 & 40.3 & 42.3 & 45.4 & 56.3 & 46.0 \\
45 & 53.0 & 59.4 & 63.6 & 68.0 & 61.0 \\
Mean & 40.1 & 47.3 & 51.7 & 58.0 & \\
\hline
\end{tabular}

${ }^{1}$ L.S.D. $=6.5$.

${ }^{2}$ L.S.D. $=5.5$.

Significant at $1 \%$ level.

\section{Height, Spread, and Seed Output in Relation to Clipping}

The spread of plants increased gradually with decrease of time of clipping interval. Maximum spread of the plant was noted when it was clipped at $5 \mathrm{~cm}$ in each set of the experiment. The height of the plant increased gradually with increased intervals of time. Thus, a linear relation was formed in case of height versus interval of clipping time (Table 3).

A count of the number of spikes was made at the time of seed maturity in all the treatments, and the number of filled caryopsis was determined. Evidently, treatments producing high forage yields likewise produced high seed yields. Closer and increased clipping frequency decreased both the number of spikes and the number of caryposis/spikes. Similarly, Whitman and Helgeson (1946), Blaisdell and Pechanec (1949), and Cook et al. (1958) observed that frequent and intense clipping of grasses reduces the number of spikes and the number of viable seed/spike. 
Table 3. Height, spread, and tiller formation in relation to clipping. ${ }^{1}$

\begin{tabular}{|c|c|c|c|c|c|c|c|}
\hline \multirow{2}{*}{$\begin{array}{l}\text { Clipping } \\
\text { height } \\
\text { (cm) }\end{array}$} & \multirow[t]{2}{*}{$\begin{array}{l}\text { Clipping } \\
\text { frequency }\end{array}$} & \multirow[t]{2}{*}{$\begin{array}{c}\text { Clipping } \\
\text { interval } \\
\text { (days) } \\
\end{array}$} & \multicolumn{2}{|c|}{$\begin{array}{l}\text { Average height } \\
\text { of plant }{ }^{2}(\mathrm{~cm})\end{array}$} & \multicolumn{2}{|c|}{$\begin{array}{l}\text { Average spread } \\
\text { of plant }^{2}(\mathrm{~cm})\end{array}$} & \multirow{2}{*}{$\begin{array}{l}\begin{array}{c}\text { Average number } \\
\text { of tiller per plant }\end{array} \\
29 \pm 1.5\end{array}$} \\
\hline & & & 37.2 & \pm 1.3 & 16.4 & \pm 1.9 & \\
\hline Base & 6 & 15 & 18.3 & 2.3 & 30.3 & 0.3 & $29 \pm 1.1$ \\
\hline 5 & 6 & 15 & 25.4 & 1.3 & 32.3 & 0.9 & $36 \pm 1.3$ \\
\hline 10 & 6 & 15 & 27.9 & 1.5 & 30.4 & \pm 1.3 & $32 \pm 1.5$ \\
\hline 15 & 6 & 15 & 37.9 & 1.8 & 29.3 & \pm 2.6 & $37 \pm 0.7$ \\
\hline Base & 3 & 30 & 16.3 & 2.7 & 20.4 & \pm 1.1 & $30 \pm 2.1$ \\
\hline 5 & 3 & 30 & 26.3 & \pm 0.3 & 25.3 & 1.9 & $33 \pm 0.9$ \\
\hline 10 & 3 & 30 & 36.5 & $\pm \quad 1.1$ & 24.9 & 2.6 & $37 \pm 0.6$ \\
\hline 15 & 3 & 30 & 43.9 & \pm 2.3 & 20.3 & 0.7 & $49 \pm 1.3$ \\
\hline Base & 2 & 45 & 21.3 & \pm 1.9 & 15.3 & 3.8 & $32 \pm 1.9$ \\
\hline 5 & 2 & 45 & 29.3 & \pm 1.3 & 24.9 & 1.9 & $49 \pm 2.3$ \\
\hline 10 & 2 & 45 & 44.3 & $\pm \quad 1.9$ & 23.1 & 1.5 & $50 \pm 2.9$ \\
\hline 15 & 2 & 45 & 54.3 & \pm 1.5 & 20.7 & \pm 1.7 & $59 \pm 1.3$ \\
\hline
\end{tabular}

Mean \pm standard deviation.

${ }^{2}$ Average is based on 25 counts.

Table 4. Seed output per plant under various treatments.

\begin{tabular}{cccccc}
\hline \hline \multirow{2}{*}{$\begin{array}{c}\text { Clipping } \\
\text { intervals } \\
\text { (days) }\end{array}$} & \multicolumn{5}{c}{ Clipping height $(\mathrm{cm})^{2}$} \\
\hline 15 & Base & 5 & 10 & 15 & Mean \\
\hline 30 & 216 & 275 & 293 & 353 & 284 \\
45 & 319 & 369 & 295 & 465 & 387 \\
Mean & 383 & 396 & 469 & 593 & 460 \\
& 306 & 346 & 385 & 470 & \\
\hline${ }^{1}$ L.S.D. $=49.6$ & & & & & \\
${ }^{2}$ L.S.D. $=43.0$ & & & & \\
Significant at 1\% level. & & & &
\end{tabular}

In general it is logical to believe that if herbage is removed closely and frequently, the amount of food materials available for translocation to the roots is reduced. This in turn reduces vigor of the plant and its capacity to produce herbage and roots and consequently the number of seed.

\section{Literature Cited}

Albertson, F. W., A. Reigel, and J. L. Launchbaugh. 1953. Effects of different intensities of clipping on short grasses in West Central Kansas. Ecology. 34:1-12.

Aldous, A. E. 1930. Effect of different clipping treatments on yield and vigor of prairie grass vegetation. Ecology. 11:752-759.

Baker, M. L., V. N. Arthand, E. C. Conard, and L. C. Newell. 1945. Effect of time of cutting on yield and feeding values of prairie hays. Nebr. Agr. Exp. Sta. Bull. 388.

Biswell, H. H., and J. E. Weaver. 1933. Effect of frequent clipping on the development of root and tops of grasses in prairie sod. Ecology. $14: 358-390$.

Blaisdell, J. P., and J. F. Pechanec. 1949. Effects of herbage removal at various dates on vigor of bluebunch wheatgrass and arrowleaf balsam root. Ecology. 30:298-305.

Bor, N. L. 1941. Common grasses of the United Provinces. Indian. Forest. Rec. N. S. Bot. 2(1):1-220.

Brown, E. M. 1943. Seasonal variation in growth and chemical composition of Kentucky bluegrass. Mo. Agr. Exp. Sta. Res. Bull. $360.76 \mathrm{p}$.
Buckner, G. D., and A. H. Henry. 1945. Composition and yield of Kentucky bluegrass and Korean lespedoza at different stages of growth. Ky. Agr. Exp. Sta. Bull. 473. 12 p.

Canfield, R. H. 1939. The effect of intensity of frequency of clipping on density and yield of black grama and tobosa grass. U.S. Dep. Agr. Tech. Bull. 681.32 p.

Cook, C. W., L. A. Stoddard, and F. E. Kinsinger. 1958. Responses of crested wheatgrass to various clipping treatments. Ecol. Monogr. 28:237-272.

Daubenmire, R. F. 1947. Plants and environment. John Wiley and Sons, N.Y.

Harrison, C. M. 1931. Effect of cutting and fertilizer applications on grass development. Plant Physiol. 6:669-684.

Lovvorn, R. L. 1945. The effect of defoliation, soil fertility temperature and length of day on the growth of some perennial grasses. J. Amer. Soc. Agron. 37:570-582.

McCarty, E. C. 1932. Some relations between the carbohydrates and the growth rate in the wild oat, Avena fatua. Riverside, Calif. J. Coll. Occas. Pap. 8:1-32.

Owensby, C. E., and K. L. Anderson. 1969. Effect of clipping date on loamy upland bluestem range. J. Range Manage. 22:351-354.

Robinson, Q. R., V. G. Sprague, and A. G. Luck. 1952. The effect of irrigation, nitrogen, fertilization and clipping treatment on persistence of clover on total and seasonal distribution of yield in a Kentucky bluegrass sod. Agron. J. 44:239-244.

Singh, V. P. 1969. Ecology of grasslands of Ujjain. PhD Thesis. Vikram Univ., Ujjain, India.

Smith, G. J., J. Elston, and A. H. Bunting. 1971. The effect of cutting and fertilizer treatment on the yield and botanical composition of Chalkturf. J. Br. Grassl. Soc. 26:213-219.

Stapledon, R. G., and A. R. Beddows. 1926. The quantitative and qualitative response of Cooksfoot (Dactylis glomerata L.) to Sodium nitrate and to superphosphate. Welsh. J. Agr. 3:103-113.

Stoddart, L. A. 1946. Some physical and chemical responses of Agropyron spicatum L. to herbage removal at various seasons. Utah Agr. Exp. Sta. Bull. 324. 24 p.

Weinmann, H. 1943. Yields and chemical composition of pasture herbage as influenced by fertilizing and frequent clipping. South Afri. J. Sci. 40:127-134.

Whitman, W. C., and E. A. Helgeson. 1946. Range vegetation studies. North Dak. Agr. Exp. Sta. B ull. 340.43 p.

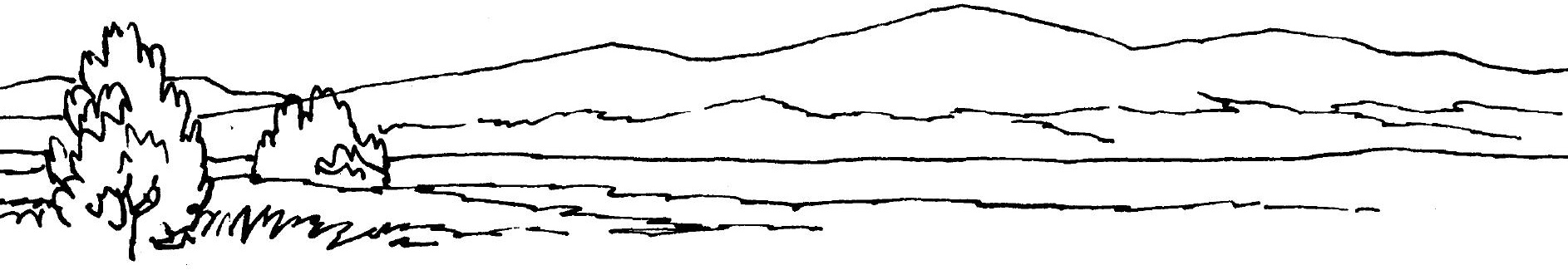

